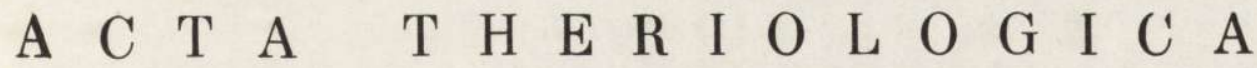 \\ VOL. XII, 33: $481-486$ \\ BIAEOWIEŻA \\ 30.XII.1967
}

Leon Z A N I E W S K I

\section{Observations on the Cross-Breeding the European Bison With Domestic Cattle of the Polish Red Breed \\ Bisoniana XXXIV}

[With 2 Figs. \& 1 Table]

\begin{abstract}
Experiments were made from 1958-1965 on cross-breeding the wisent Bison bonasus (L.) with domestic cattle of the polish red breed (Bos taurus dom. L.). One female hybrid was obtained. The hybrid was successfully covered by a Jersey bull. The hybrid $\mathbf{F}_{1}$ was distinguished by rapid physical development, particularly as regards increase in weight ( $48 \mathrm{~kg}$ at birth, $600 \mathrm{~kg}$ at the age of 2.5 years), and good health.
\end{abstract}

Professor Mieczysław ${ }^{\circ} \mathrm{C} z$ a ja, D. Sc, was the initiator of a series of experiments on the cross-breeding the European bison with domestic cattle of the polish red breed in the Experimental Station at Popielno. The bull wisent, "Pug II" (no. 1087), born on December 13 th 1957 at Borki, was brought to Popielno in February 1958 and at first kept in the calves' enclosure together with domestic cattle. After a few months it was transferred to a wooded enclosure 1.7 ha in area at a distance of about $2 \mathrm{~km}$ from Popielno. The enclosure was situated on the banks of Lake Bełdan, at the edge of which a drinking place was arranged. Four polish red heifers several months old were then introduced into the enclosure. After the heifers had attained sexual maturity in 1960 the wisent began to cover them repeatedly. Two of these heifers, "Wolna" (born March 15th 1959) and "Wisełka ", were covered for the last time by "Pug II" at the end of April 1961. Two months later (from the last time of covering) these heifers exhibited improvement in their state of nutrition, expressed primarily in the rounding of their forms and their glistening coats. As the symptoms characteristic of the final period of pregnancy intensified in "Wolna " it was taken to Popielno in order to ensure it better care ${ }^{1}$ ).

1) The remaining heifers were sold. "Wiselka aborted an embryo, about five months old, sired by the wisent, at her new owner's. This took place probably immediately after rectal examination - the third successive examination to be made during this heifer's pregnancy. 
After 261 days of pregnancy »Wolna " gave the impression of being in process of parturition, but neither the vulva was ready for birth nor the milk glands ready to receive the nowly-born calf. After approximately 24 hours the heifer became calm and the later period of pregnancy revealed no deviations from the normal.

On February 20th 1962 at 8,00 a.m. "Wolna" gave birth to a female hybrid $F_{1}$ weighing $48 \mathrm{~kg}$, after 299 days of pregnancy. The position of the embryo was normal and on account of its size the birth took place forcibly with the assistance of two men within 15 minutes. The cow as once began caring for the calf, excitement while doing so, which subsided when the hybrid began to suck. This took place 30 minutes after the birth and after a further 90 minutes the beestings were avacuated by the hybrid. The placenta had to be artificially detached from "Wolna ".

"Famela « ${ }^{2}$ ) was more similar after birth to a wisent than domestic cattle as regards silhouette and build (Photo 1). The colour of the hybrid's coat began to darken from the head in a caudad direction. Later moulting took place in a similar order. The calf had a darker coat than either cow or wisent by the time it was several months old (Photo 2). Small white patches in "Famela's" uniform dark brown coat were located on the upper lip and round the nostrils (Photo 3 ). The hybrid had inherited inter alia from the wisent a low-toned voice, stratiform structure of the horn tissue and the mental characteristics of an undomesticated animal. These last were particularly marked when subduing "Famela". The skittishness of the hybrid gradually decreased as the animal became older under the influence of domesticating factors (feeding, watering, cleaning and grooming the coat, frequent zoometric measurements and weighings, and grazing together with domestic cattle in the pasture).

"Famela " remained with "Wolna " 3 ) for 5 months and during this time kept close to the cow, but later the hybrid enjoyed unlimited freedom for over a year. Neither ordinary nor electric fences formed any obstacle to the animal.

During the period of over two months which the hybrid spent with "Pug II « it was covered by the bull at the age of 22.5 months. This age was taken as the attainment by "Famela " of sexual maturity. After the death of the wisent ${ }^{4}$ ) "Famela " returned to Popielno of her own accord within a few days. As rectal examination revealed the hybrid's sterility ( $\mathrm{Z}$ aniewski, 1967) it was again covered on August 15th and 16th

2) The original name given was "Pamela" (cf. $\mathrm{Kr}$ a siń s k a, 1967).

3) "Wolna " was slaughtered August 3rd, 1962.

4) "Pug II" died February 7th 1964 during the experiment with suxamethonium (J a c z ewski \& $\mathrm{Z}$ ur owski, personal communication). 
1964 by a young bull of the Charoilaise breed, but also without effect. "Famela" was next covered several times by a domestic bull of the Jersey breed, no. 32, for the last time in December 16th 1964. "Famela " was bought by the Mammals Research Institute, Polish Academy of Sciences and taken to Białowieża on July 29th 1965, where she gave birth to the hybrid ( $3 / 4$ cattle), a male, called "Fey", on September 16 th, 1965 (K r a sińs k a, 1967).

The animals were artificially fed once daily, amount depending on the individual needs of the animal, except that the hybrid also grazed in the pasture during the spring and summer period. During the first

Table 1.

Body measurements of the hybrid Famela during the postnatal development.

\begin{tabular}{|c|c|c|c|c|c|c|}
\hline Dimensions in $\mathrm{cm}$ & $\begin{array}{c}7 \\
\text { days }\end{array}$ & $\begin{array}{c}6 \\
\text { months }\end{array}$ & $\begin{array}{c}1 \\
\text { year }\end{array}$ & $\begin{array}{c}1.5 \\
\text { year }\end{array}$ & $\begin{array}{c}2 \\
\text { years }\end{array}$ & $\begin{array}{c}2.5 \\
\text { years }\end{array}$ \\
\hline Height at withers & 84 & 117 & 135 & 137 & 144 & 145 \\
\hline Height at top of back & 80 & 119 & 137 & 138 & 145 & 148 \\
\hline Height at loins & 84 & 120 & 136.5 & 142 & 147 & 148 \\
\hline Length of neck and trunk & 87 & 161 & 180 & 192 & 205 & 208 \\
\hline Diagonal length of trunk & 75 & 117 & 130 & 150 & 153 & 157 \\
\hline Circumference of thorax & 88 & 155 & 180 & 186 & 203 & 211 \\
\hline Depth of thorax & 28 & 58.5 & 66.5 & 72 & 76.5 & 78.5 \\
\hline Breadth of thorax & 16.5 & 37 & 40.5 & 44.5 & 45 & 48 \\
\hline Breadth at shoulders joints & 19.5 & 37 & 43 & 45 & 49 & 50 \\
\hline Breadth of pelvis & 18 & 33 & 41 & 46 & 51 & 52 \\
\hline Length of pelvis & 26 & 44 & 50 & 54.5 & 57 & 58 \\
\hline Breadth of hip-bones & 6 & 12 & - & 13 & 13.5 & 14 \\
\hline Height of head & 16 & 41 & 47 & 51 & 55 & 55 \\
\hline Breadth of head & 14 & 21 & 23 & 24 & 25 & 25 \\
\hline Narrowness of forehead & 9 & 13 & 13 & 14 & 16 & 16 \\
\hline Circumference above hock of fore leg & 12.5 & 17 & 19 & 19.5 & 21 & 21 \\
\hline Circumference above hock of hind leg & 12.5 & 19.5 & 21 & 22 & 23 & 23 \\
\hline Length of tail with tuft & - & - & - & 130 & 135 & 139 \\
\hline Length of horns along curvature & 0 & 12 & 22 & 27 & 28 & 32 \\
\hline Horn span & - & - & - & 47 & 48 & 48 \\
\hline
\end{tabular}

5 months of its life "Famela" had "Wolna's" milk as its basic food. Up to the age of 8 months the hybrid was given decreasing portions of milk, beginning with $9 \mathrm{l}$ daily: the milk was supplied by a Jersey cow, the fat contents of the milk of which were similar to that of "Wolna's " milk, which 2 months after calving had $5.1 \%$ fat. The basic food of the animals, including the hybrid, over the age of 6 months, consisted of coarse ground oatmeal, bran, urea-treated mixture B, green fodder, hay, fodder beet, ensilage from maize with the addition of vitamins, micro-elements and also the leaves and young shoots of trees and shrubs. The hybrid at the age of 2.5 years received: $5 \mathrm{~kg}$ of coarse-ground oatmeal, $1 \mathrm{~kg}$ mixture B, $20 \mathrm{~kg}$ green fodder (alfalfa) and grazing on the pasture. 
The health of the animals was in general very good. The repeated tuberculinisation of the heifers and single tuberculinisation of the hybrid (at the age of 4.5 months) gave negative results. The wisent manifested apathy and loss of appetite during the first days of solitude. "Famela " reacted similarly to isolation. The hybrid was immunised on November 6th 1962 for foot-and-mouth disease (vaccine series: OWCU-36). At the age of 1.5 years "Famela's" pulse was 56 per minute; respiration 24 and rectal temperature $39.1^{\circ} \mathrm{C}$. »Famela's « good health and

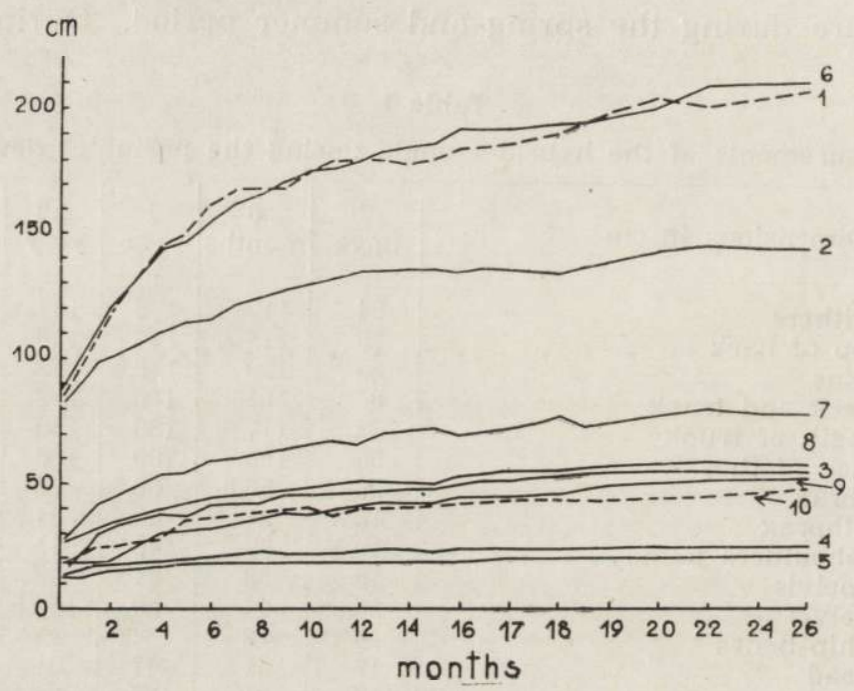

Fig. 1. Increase in 10 parameters of $\times$ Famela's " physical development. The remaining parameters are similar in course taken by increase.

1 - Lenght of neck and trunk of the body; 2 - Height at withers; 3 - Height of head; 4 - Breadth of forehand; 5 - Circumference fore leg up fetlock; 6 - Circumference of thorax; 7 - Depth of thorax; 8 - Breadth of thorax; 9 - Lenght of pelvis; 10 - Breadth of pelvis.

good resistance were confirmed during the experiments with suxamethonium and neostigmine ( $\mathrm{Z}$ a n i ewski, 1967).

The physical development of the hybrid was recorded by zoometric measurements (23 times) (Table 1, Fig. 1) and measurements of body weight (57 measurements) (Fig. 2). The body dimensions of the animal, which were established earliest at the age of 2 years, refer to the head and circumference above the hock of its limbs (Table 1, Fig. 1).

The rate of weight increase in "Femala " (Fig. 2) was characterised by two periods, the first from 0 to 8 th months, and the second from 9 to 31 months of life. This division was confirmed by statistical calculations: rate of growth increase in the hybrid from months $0-8$ was expressed 
by the function $\mathrm{y}=1.022 x+55.31$ and from months $9-31: \mathrm{y}=0.4449 x$ + 191.16. The deflection of the empirical curve (Fig. 2) about the 5 th month is probably connected with "Famela's* separation from its mother and weaning. The second deflection in the empirical curve at the meeting place of the two periods at the 8th month of the hybrid's life was probable due to the cessation of the milk supply and transition from summer to winter feeding. The mean daily increase during the first period was $1.069 \mathrm{~kg}$ in the hybrid, and $0.418 \mathrm{~kg}$ in the second.

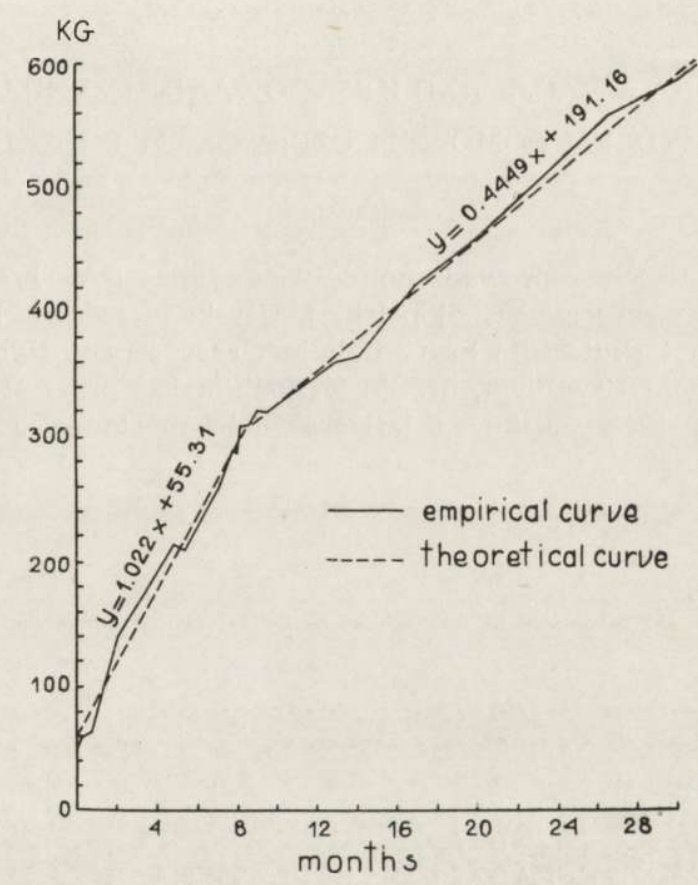

Fig. 2. Growth rate of body weight of hybrid $F_{1}$ from 0 to 31 months.

The dynamic physical development of the hybrid is remarkable, particular increase in body weight. At the age of 2.5 years "Famela" weighed $600 \mathrm{~kg}$. Bulls of one of the polish red breeds do not exhibit identical weight until the age of 4.5 years $(\mathrm{Szczekin}-\mathrm{Krotow}$ et al., 1955).

\section{REFERENCES}

1. Krasińska M., 1967: Crosses of wisent and domestic cattle. Part V. Acta theriol., 12, 5: 67-79.

2. Szczekin-Krotow W, Lewicki Cz. \& Trzaskowski J., 1955: Badania nad bydłem czerwonym polskim powiatu Wysokie Mazowieckie. Rocz-ki Nauk. Rol., 72-D: 1-223. 
3. Z a n i ewski L., 1967: Immobilization of European bison $\times$ cattle hybrid with suxamethonium. Acta theriol., 12, 33: $471-474$.

Received, April 20, 1967.

Polish Academy of Sciences,

Institute of Experimental Animal Breeding,

Experimental Station at Popielno, Poland.

\section{Leon ZANIEWSKI}

\section{OBSERWACJE NAD KRZYŻOWANIEM ŻUBRA \\ Z BYDEEM DOMOWYM CZERWONYM POLSKIM}

Streszczenie

W latach 1958-1965 przeprowadzono doświadczenia nad krzyżowaniem żubra z bydłem domowym rasy czerwonej polskiej. Uzyskano jednego hybryda płci żeńskiej. Hybryd $F_{1}$ był skutecznie kryty buhajem rasy jersey. Hybryd $F_{1}$ wyróżniał się szybkim rozwojem fizycznym, przede wszystkim zaś przyrostem ciężaru (48 kg przy urodzeniu, $600 \mathrm{~kg}$ w wieku 2,5 lat) oraz dobrym stanem zdrowotnym.

\section{EXPLANATION OF PLATE XXIII.}

Photo 1. "Famela" at about 3 days old.

Photo 2. A $3^{1 / 2}$ months old hybrid "Famela" on the balance.

Phot. 3. "Famela" at the age of 27 months during the making of zoometric measurements. 


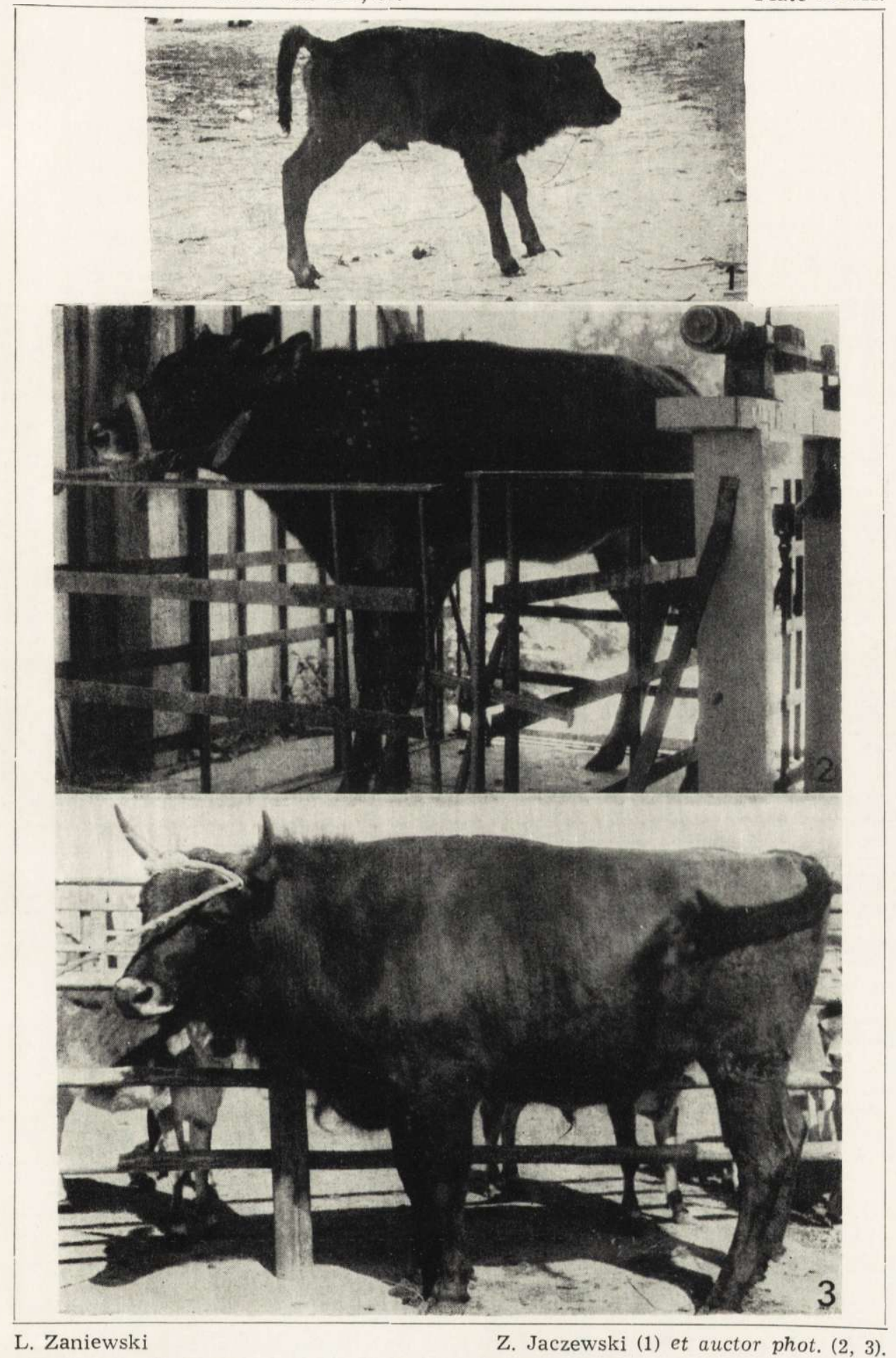

